\title{
CRITICAL THINKING BASED INTERACTIVE LEARNING MEDIA FOR BASIC MECHANICAL ENGINEERING
}

\author{
Aam Amaningsih Jumhur ${ }^{1, ~ *}$, Ratu Amilia Avianti², Anya Tamara Akbar ${ }^{3}$ \\ 1, 2, 3Department of Mechanical Engineering Education, Universitas Negeri Jakarta, Jl. Rawamangun Muka Raya, \\ Rawamangun, Pulo Gadung, Kota Jakarta Timur, Daerah Khusus Ibukota Jakarta 13220, Indonesia \\ E-mail: aam_yd@yahoo.co.id * \\ *Corresponding Author
}

\begin{abstract}
Recent studies show limited research on the development of learning media that effectively addresses critical thinking, communication, collaboration, and creativity $(4 \mathrm{C})$ characteristics. However, there is an urge for nurturing the $4 \mathrm{C}$ characters of vocational high school graduates in the $21^{\text {st }}$ Century, especially critical thinking. Hence, this study aims to develop and discover the feasibility, usability, and effectiveness of critical thinkingbased interactive learning media for Basic Mechanical Engineering. This study used the Analysis, Design, Development, Implementation, and Evaluation (ADDIE) development concept. The information design in developing the learning media was based on critical thinking aspects by Facione in ATC21S. The criticalthinking-based interactive learning media (CTBILM) were developed for mobile learning which can be used in IOS and Android. The alpha test showed promising results, especially from material experts. In addition to that, the User Acceptance Test (UAT) also shown a significant score making CTBILM quite feasible. We also argue that the significant change in student critical thinking from the statistical t-test on pretest and posttest are due to CTBILM.
\end{abstract}

Keywords: basic mechanical engineering subjects, critical thinking, learning media, mobile learning, vocational high school

\section{INTRODUCTION}

Indonesia will enter the era of Demographic Bonus in 2020 [1]. It will have positive impacts if graduates have the potential competency to become the pillar of economic development through the utilization of human resources yet if the graduates cannot meet the expected qualification and competencies to meet the labor demands, this will have a negative economic impact such as the rise of the unemployment rate [2]. Hence, it can be concluded that the education and learning standard needs to be in line with the requirement of the $21^{\text {st }}$ Century skills to align human resources with labor demands required to meet the Demographic Bonus challenge.

Law Number 20 the Year 2003 about the Indonesian National Education System article 15 and article 36 stated that the vocational secondary education level aims to prepare students to have competencies required by the working field. However, according to the data, the education level with the highest unemployment rate is the vocational high school with the percentage of $13.55 \%$ [3]. The gap between the soft skill competencies taught in vocational high school and the needs of soft skill competencies from the industrial world are one of the reasons for the poor employment rate of vocational high school graduates [4]. It indicates that vocational high schools have failed to meet the soft skills competencies required in the $21^{\text {st }}$ Century.

$21^{\text {st }}$-century learning is required to be based on Information, Communication, and Technology (ICT) to support students in acquiring the life skills needed in the $21 \mathrm{st}$ century [5]. Moreover, learning in the $21^{\text {st }}$ century aims to prepare students to master ICT and develop soft skills with critical thinking, communication, collaboration, and creativity (4C) criteria [5], [6].

One of the efforts to form critical thinking is to teach the ability to utilize ICT [7]. ICT-based learning media is considered an 
effective strategy to increase the critical thinking skills required in a technology-based era [8]. Based on this statement, the learning process should be shifted and focused on both aspects, optimization of ICT utilization ability and $4 \mathrm{C}$ characters thus the graduates of vocational high schools can compete in the industrial world of the $21^{\text {st }}$ Century.

Critical thinking is one of the essential abilities to prepare students to become a workforce that is qualified with the $21 \mathrm{st}$ Century competencies [9]. Critical thinking is the most essential skill in the work environment [10]. Hence, critical thinking is an urgentlyneeded skill to be taught to the students to meet the labor demands [11], [12].

There is a significant correlation between students' ability to think critically and learning environments utilizing ICT [13]. ICT-based learning media such as the mobile learning application increase students' critical thinking if the design of the information is supporting the purpose [14]. The Strategic Plan of the Indonesian Ministry of Education and Culture 2020-2024 also stated that one of the challenges faced by the learning process in Indonesia is to shift manual learning to become ICT-facilitated learning. Therefore, the use of ICT in the learning process, such as mobile learning, is one strategy to help students develop critical thinking skills and shift from manual learning [15], [16].

Mobile learning is one of the ICT-based learning media solutions to tackle the issue caused by manual learning [17]. Mobile learning is accepted by the majority of the education industry due to its effectiveness in delivering information anytime and anywhere [18]. The ICT-based learning media can be used as a tool to increase the skills required in the $21^{\text {st }}$ Century especially in the aspects of information management [19]. Various studies have shown the potential of mobile learning for increasing the $21^{\text {st }}$ Century skills such as $4 \mathrm{C}$ character yet the subjects in vocational high school are understudied [22]. Hence, this study develops and explores the potential of mobile learning application for one of the subjects of vocational high school to increase the critical thinking skills which is one of the aspects of $4 \mathrm{C}$ characters.

Basic Mechanical Engineering is one of the subjects in mechanical engineering vocational high school which includes general knowledge related to various work processes in mechanical engineering such as metal casting, bench work, welding, grinding, and measuring. Students are expected to be able to solve problems based on the basis given to the Basic Mechanical Engineering subjects in practicum activities and advanced subjects that are more specific on each topic of the Basic Mechanical Engineering material. Based on this explanation, there is a high urgency for designing critical thinking-based learning media by utilizing ICT for mobile learning to meet the 21st Century learning standard for Basic Mechanical Engineering.

\section{METHOD}

The method of this study is Research and Development with ADDIE. It is a development model mostly used in developing learning media [20], [21]. According to Dick and Carey, ADDIE consists of (1) analysis, (2) design, (3) development, (4) implementation, and (5) evaluation [22]. The stages of this study are illustrated in Figure 1.

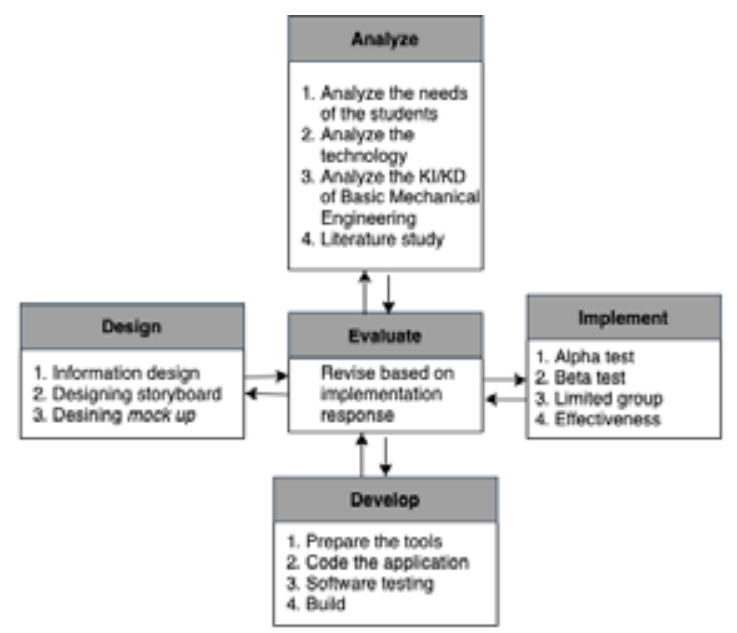

Figure 1. The Stages of the Study 
The data in this study were collected using the following techniques: questionnaire, (2) interview, (3) test, (4) observation. The questionnaire used in the study is the 5-Point Likert Scale. The interviews were conducted to discover the perspective of teachers and students regarding CTBILM. The purpose of observation is to examine the ability of students to operate CBILM.

The instruments of the study are (a) media feasibility validation questionnaire for linguists, (b) media feasibility validation questionnaire for media experts, (c) media feasibility validation questionnaire for material experts, and (d) UAT validation questionnaire for students, and (e) critical thinking test for Basic Mechanical Engineering based on the aspect of California Critical Thinking Disposition Inventory [23]. Media feasibility questionnaire for experts used in the alpha test. The UAT questionnaire was used in the beta test and UAT. The critical thinking test consisted of pretest and posttest was used to analyze the effectiveness of CTBILM. The effectiveness of CTBILM was analyzed on SPSS 25 with a paired-sample t-test.

The experts in alpha testing consisted of three individuals each are the expert on media, material design of Basic Mechanical Engineering subject, and linguist. The sample of the beta test is 20 students of X TFLM 3 from SMKN (Vocational High School) 26 Jakarta. The sample of the limited group was 60 students of X TFLM 1 and X TFLM 2 while the subject of the effectiveness test of CTBILM is 34 students from X TFLM 1 selected with purposive sampling.

\section{RESULTS AND DISCUSSION}

The result of the literature study is to determine the aspects of critical thinking that need to be considered during the information design for CTBILM. The critical thinking aspects of CTBILM consist of interpretation, analysis, evaluation, inference, explanation, and self-regulation [24], [25].

The lesson of Basic Mechanical Engineering in CTBILM consists of seven lessons. The design of information and data in each lesson was based on core competencies and basic competencies for Basic Mechanical Engineering which can be concluded as follows: (1) Measurement (2) Hand-Tools (3) General machine in mechanical engineering (4) Grinding machine (5) Metal fabrication process, (6) Welding (7) Casting [26].

Based on the study, Flutter supports cross-platform development for both operating systems like IOS dan Android with the mechanism of just-in-time compilation in one codebase [27]. Besides, Flutter has various plug-in support like web-launcher, gif-loader, ar-kit, etc. which can elevate the quality and the interactivity of mobile applications. Hence, the framework used for developing CBILM is Flutter.

The information and data displayed in CTBILM are based on core competencies and basic competencies respectively with the critical thinking aspects. The information design which has been designed then proceeded to the stage of writing the script for each lesson. The design of the UI of CTBILM is shown in Table 1.

Since CTBILM is a learning media categorized as multimedia then it is needed to discover the relevance of its UI. The purpose of UI is to motivate students hence there are four elements needed to be considered attention, relevance, confidence, and satisfaction [28]. In the early phase of designing UI as shown in Table 1, the researcher interviewed 5 students in X TFLM 3 regarding their opinion of CTBILM's UI and design. Based on the interview, students stated that the overall aspects of the UI are relevant and interesting. The purpose of pre-development is to install all the required tools to develop CTBILM. The plug-in and tools used in CTBILM are described in Table 2. 
$\underline{\text { Table 1. Mock-Up of CTBILM's UI }}$

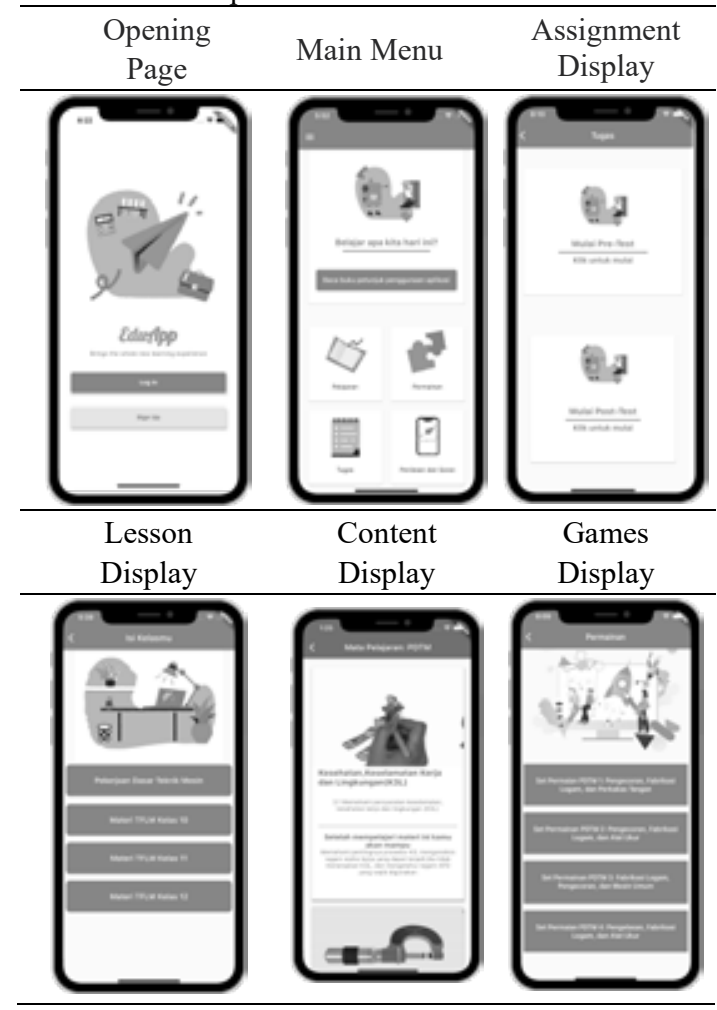

Table 2. Software for Development

\begin{tabular}{ll}
\hline \multicolumn{1}{c}{ Tools/Plugin } & \multicolumn{1}{c}{ Function } \\
\hline Web-Launcher & To launch web URL \\
Flutter 1.17 & Main frameworks \\
& To enable bottom \\
Fancy Botton Navigation & navigation \\
Android Studio & Code editor \\
Simulator & To display the application \\
\hline
\end{tabular}

Media such as images, videos, and animations which used to support each lesson collected in this stage. The next step was to pair each information design with relevant media that have been collected. The development of CTBILM started with coding the UI in Android Studio. The programming language used for developing CTBILM in Flutter is Dart. The information design and relevant media are inserted in the format of Dart code. The codebase in Dart was then compiled to create an application that can run on the smartphone. The process of coding CTBILM in Android Studio and its result in the simulator is shown in Figure 2.

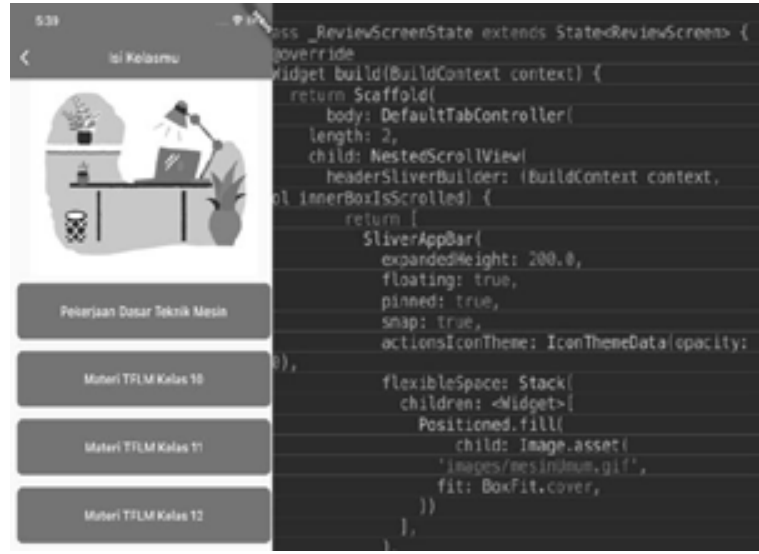

Figure 2. On-Development Phase

The next step in the on-development stage was coding the logic of the games which would be used as the evaluation for students learning process. The logic of the games was to give one point if the students answered correctly and zero if their answer was not correct. The next step after the games feature was to code the assignment feature and the feedbacks feature. The coding process of both used the Web-Launcher plugin inserted with the URL of the test page and feedback page from Google Form. The URL of the Google Form was inserted to the button implemented with the Web-Launcher plugin then when the button was clicked the application would be directed to the attached URL.

The post-development stage tested the performance of CTBILM. The test consisted of unit testing and UI testing. Unit testing was performed to discover the reliability of the codebase and to identify any bugs. The result of unit testing indicated all unit passed means there was no bugs or error in the codebase. UI testing was performed to discover the UI rendering performance of CTBILM. The result of UI testing was $15 \mathrm{fps}$ and was categorized as moderate. Figure 3 shows the result of UI testing. 


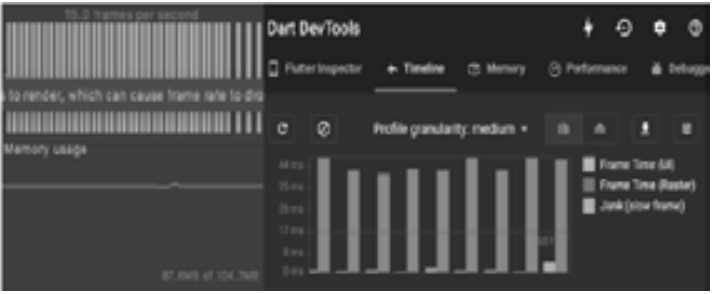

Figure 3 . The Result of UI testing

The result of software testing was passed, both for unit testing and UI testing. The next step was to build the codebase for Android and IOS. CTBILM has two formats, apk for Android and app for IOS. Both formats of CTBILM were then tested on the real device. CTBILM installation in the real device is properly worked. The format of CTBILM is available at https://bit.ly/AplikasiEduApp.

The lesson feature was the place for students to learn the information based on the selected lesson. The lesson features were divided into sub-feature consists of seven lessons. The information design in every lesson considered the six aspects of critical thinking. The example in Table 3 shows the information design of CTBILM for Safety, Health, and Environment (HSE) lesson.

The purpose of the game feature is to test the students' critical thinking regarding the lessons. The game's feature consists of four sets which can be seen in Table.4. Each set includes four problems or statements. Students are expected to interpret, analyze, evaluate, or infer and explain. The games can show the right and wrong answers for students to reflect on the result of their thinking and learning process.

The games expected students to drag and drop the given statement to the relevant picture. If students paired the wrong statements with the given picture the score would be zero and if they got the right one the score would be one. The games allow interactivity between the students and CTBILM which could increase the retention of information. The games served as the place for students to practice before taking the posttest.
Table 3. CTBILM's Role in Promoting Critical Thinking According to the Template

$\quad$ Aspects
Interpretation :
Guiding to identify
relevant
information
Clearing the stated
problem with the
support of
multimedia
-
Analysis :
Encouraging
students to recheck
the data or
information
provided.
Guiding students to
make hypotheses
to gain more
information when
created their
hypothesis by
problem based on
the relevant
information on
CTBILM
Promoting students
to re-checking the
relevancy of the
hypothesis which
they made with the
supports of
multimedia
Guiding students to
ask themselves
whether the given
information is
Enough to create a
-


Table 3. (Continued)

Aspects
Inference and Explanation :
make a logical and
systematic
statement based on
their hypothesis
regarding their
response to the
given problem
Facilitating students
to write their
statement or answer
for the given
problem
Self Regulatory :
Facilitating students
to compare their
answer with the
right answer
Promoting students
to reflect on their
answer and helping
them to inquiry new
knowledge from the
comparing activity

The purpose of the game feature is to test the students' critical thinking regarding the lessons. The game's feature consists of four sets which can be seen in Table.4. Each set includes four problems or statements. Students are expected to interpret, analyze, evaluate, or infer and explain. The games can show the right and wrong answers for students to reflect on the result of their thinking and learning process.

The games expected students to drag and drop the given statement to the relevant picture. If students paired the wrong statements with the given picture the score would be zero and if they got the right one the score would be one. The games allow interactivity between the students and CTBILM which could increase the retention of information. The games served as the place for students to practice before taking the posttest.
Table 4. Games Feature

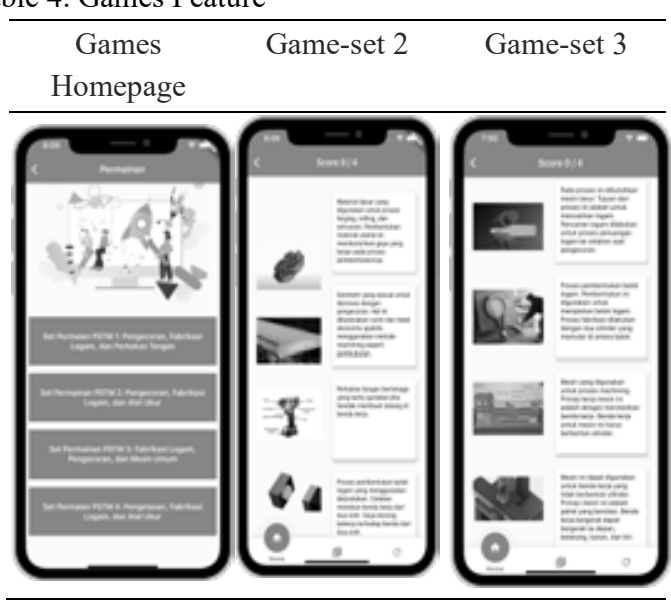

The function of the assignment feature is to facilitate students' access to their pretest and posttest. Before using CTBILM students for purposive sampling were asked to take the pretest. After the intervention of CTBILM then they were asked to take the posttest in the assignment feature. The assignments feature in CTBILM is shown in Table 5.

Table 5. Assignments and Feedbacks Features

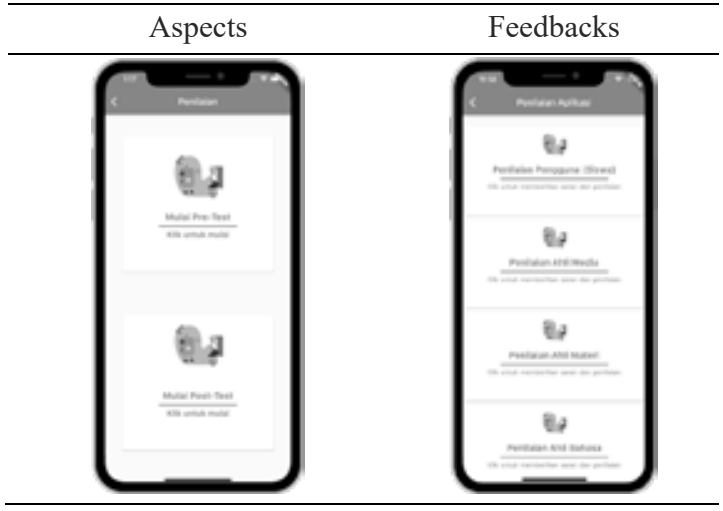

The purpose of the feedback feature is to determine if there is any bug or problem that exists. The display of the feedback feature in CBTBILM is shown in Table. 5 The students could report the problems regarding the application. The reported problem would be fixed by the researcher to avoid further issues in future usage during the implementation.

The alpha test is the ultimate testing for the expert. The material expert was the teacher of Basis Mechanical Engineering subject from SMKN 26 Jakarta, the media expert was the information-system and educational-technology 
practitioner, and the linguist was the lecturer of language major. The questionnaire of feasibility for the alpha test is based on Survey Item to Evaluate Multimedia Program and McCalls's software quality factor [29], [30]. The result of the alpha test can be described in Table 6 , Table. 7, and Table. 8.

Table 6. Result of Media Expert

\begin{tabular}{lccc}
\hline \multicolumn{1}{c}{ Aspects } & Scores & $\begin{array}{c}\text { Maximum } \\
\text { Scores }\end{array}$ & $\begin{array}{c}\text { Feasibility } \\
\text { Percentage }\end{array}$ \\
\hline General & 23 & 25 & $92 \%$ \\
Software performance & 37 & 40 & $92.5 \%$ \\
User Interface & 15 & 15 & $100 \%$ \\
Average & & & $94.8 \%$ \\
\hline
\end{tabular}

The feasibility category based on the result of the alpha test for media experts is Very Valid. The media expert suggested that CTBILM would be more engaging if it involved sounds in the Games feature. The score of UI aspects was the highest due to icon and design suitability for CTBILM.

Table 7. Result of Material Expert

\begin{tabular}{lccc}
\hline \multicolumn{1}{c}{ Aspects } & Scores & $\begin{array}{c}\text { Maximum } \\
\text { Scores }\end{array}$ & $\begin{array}{c}\text { Feasibility } \\
\text { Percentage }\end{array}$ \\
\hline General & 24 & 25 & $96 \%$ \\
Lesson design & 42 & 45 & $93.3 \%$ \\
Lesson coverage & 29 & 30 & $96.6 \%$ \\
Average & & & $95 \%$ \\
\hline
\end{tabular}

Based on the result of the material expert CTBILM can be categorized as Very Valid. The highest score was obtained by lesson coverage aspects. The coverage of CTBILM for Basic Mechanical Engineering includes all core competencies and basic competencies followed with the activity and question to stimulated critical thinking in every lesson.

Table 8. Result of Linguist

\begin{tabular}{lccc}
\hline \multicolumn{1}{c}{ Aspects } & Scores & $\begin{array}{c}\text { Maximum } \\
\text { Scores }\end{array}$ & $\begin{array}{c}\text { Feasibility } \\
\text { Percentage }\end{array}$ \\
\hline General & 19 & 25 & $76 \%$ \\
Readability & 8 & 10 & $80 \%$ \\
Grammar & 12 & 15 & $80 \%$ \\
Average & & & $78 \%$ \\
\hline
\end{tabular}

The category of CTBILM feasibility based on the alpha test for the linguist is "Very Feasible". The score of readability and grammar is mediocre. The result of language aspects is lower than media and material due to terminology inconsistency.

The beta test is a test of revised CTBILM based on the recommendation of experts. Beta test's sample consisted of 20 students from X TFLM 3 which counts for $>10 \%$ of the overall population. The students were chosen randomly by the teacher. Selected students had various ranges of ability from the low, medium, and high. The questionnaire consisted of 25 questions based on Survey Item to Evaluate Multimedia Program [29]. The result of the beta test is presented in Table 9.

Table 9. Beta Test Results

\begin{tabular}{lccc}
\hline Aspects & Scores & $\begin{array}{c}\text { Maximum } \\
\text { Scores }\end{array}$ & $\begin{array}{c}\text { Feasibility } \\
\text { Percentage }\end{array}$ \\
\hline General & 22.85 & 25 & $91.4 \%$ \\
Content & 13.8 & 15 & $92 \%$ \\
Structure & 13.95 & 15 & $93 \%$ \\
Navigation & 13.74 & 15 & $91.6 \%$ \\
Format and Layout & 18.64 & 20 & $93.2 \%$ \\
Overall quality & 9.23 & 10 & $92.3 \%$ \\
Average & & & $92.4 \%$ \\
\hline
\end{tabular}

All aspects of the questionnaire were categorized as Very Feasible. The highest-rated aspect was format and layout that scored $93.2 \%$. The lowest-rated aspect in the beta test was the general aspect. The general aspect determined the perspective of students on whether CTBILM can potentially become learning media. However, the general aspect's score still can be categorized as Very Feasible. Hence, the average score of the beta test result is $92.4 \%$ with the Very Feasible category. Based on the result of the beta test CTBILM is feasible and suitable to be used as a tool for learning Basic Mechanical Engineering subjects.

UAT was conducted to discover students' responses in a larger percentage than the beta test. The sample of UAT was 60 students from $\mathrm{X}$ TFLM 1 and X TFLM 2. The sample for UAT counted for approximately $55 \%$ of the overall population of class X in SMKN 26. The results of UAT are shown in Table 10. 
Table 10. UAT Results

\begin{tabular}{lccc}
\hline \multicolumn{1}{c}{ Aspects } & Scores & $\begin{array}{c}\text { Maximum } \\
\text { Scores }\end{array}$ & $\begin{array}{c}\text { Feasibility } \\
\text { Percentage }\end{array}$ \\
\hline General & 21.52 & 25 & $86.5 \%$ \\
Content & 13.07 & 15 & $87.1 \%$ \\
Structure & 13.22 & 15 & $88.1 \%$ \\
Navigation & 12.82 & 15 & $85.4 \%$ \\
Format and Layout & 17.27 & 20 & $86.4 \%$ \\
Overall quality & 8.65 & 10 & $86.5 \%$ \\
Average & & & $86.7 \%$ \\
\hline
\end{tabular}

The average feasibility percentage of the large group test was 86.7 with the Very Feasible category. The lowest-rated aspect was the navigation aspect with $85.4 \%$ yet still can be categorized as Very Feasible. The highestrated aspect is the structure aspect with $88.1 \%$. All aspects' feasibility percentages fall in the Very Feasible category. Hence, the conclusion was CTBILM could be utilized as a learning tool for Basic Mechanical Engineering subjects.

A summative test was conducted to determine the effectiveness of CTBILM. The summative test consists of 20 multiple-choice questions based on the critical thinking aspect in ATC21S and core competencies and basic competencies of Basic Mechanical Engineering. The summative test was conducted with pretest and posttest. There were 34 students from $\mathrm{X}$ TFLM 1 selected for purposive sampling. The purpose of the summative test was to determine the level of students' critical thinking before and after the intervention of CTBILM.

The level of critical thinking can be divided into five levels. The five levels of critical thinking are (1) Excellent (2) Good (3) Moderate (4) Weak and (5) Very Weak. The range of scores for critical thinking level can be categorized as shown in Table 11 [31].

Table 11. Category of Critical Thinking

\begin{tabular}{cc}
\hline Category & Range \\
\hline Excellent & 80 to 100 \\
Good & 60 to 79 \\
Moderate & 40 to 59 \\
Poor & 20 to 39 \\
Very Poor & 0 to 19 \\
\hline
\end{tabular}

Based on Table 12 the majority of students' critical thinking level is Moderate before the intervention of CTBILM. However, 1 student appeared to have an excellent level of critical thinking which was not common. The posttest result showed that students with a poor level of critical thinking could improve. 5 students in poor level dropped to 0 in posttest and moderate level dropped from 20 to 0 . In the pretest, 8 students had a good critical thinking level. The posttest result shown only 7 students had good critical thinking levels while the majority of students were at an excellent level after the treatment. The result of the pretest and posttest shown the potential of CTBILM to improve students' critical thinking. The improvement of critical thinking was assumed due to external stimulation from the learning media in the form of multimedia and interactive feature which increase motivation. Motivation and autonomy of learning hold an important role in nurturing critical thinking in students during the learning process [32].

Table 12. Number of Students Based on Critical Thinking Category

\begin{tabular}{lcc}
\hline \multicolumn{1}{c}{ Category } & \multicolumn{2}{c}{ Number of Students } \\
\hline & Pretest & Posttest \\
\hline Excellent & 1 & 27 \\
Good & 8 & 7 \\
Moderate & 20 & 0 \\
Weak & 5 & 0 \\
Very weak & 0 & 0 \\
\hline
\end{tabular}

The result of the pretest and posttest was then analyzed with a t-test. As a prerequisite for the t-test, the data should be distributed normally. The Shapiro-Wilk normality test appears to be more accurate for $\mathrm{n}<50$ [33]. Hence, the normality test used in this study was the Shapiro-Wilk test with $\alpha=5 \%$. Based on the result of the Shapiro-Wilk test in Table 13, the value of $p>0.05$ for both data of pretest and posttest. Hence, it can be concluded the data were distributed normally. The pretest and posttest data then can be analyzed with paired sample t-test. 
Table 13. SPSS 25 Normality Test

\begin{tabular}{ccccccc}
\hline Pair & \multicolumn{3}{c}{$\begin{array}{c}\text { Kolmogorov- } \\
\text { Smirnov }\end{array}$} & \multicolumn{3}{c}{ Shapiro-Wilk } \\
\hline & statistic & $\mathrm{df}$ & Sig. & statistic & $\mathrm{df}$ & Sig. \\
Pretest & .190 & 334 & .003 & .951 & 334 & .136 \\
Posttest & .142 & 334 & .081 & .941 & 334 & .067 \\
\hline
\end{tabular}

The result of SPSS 25 paired t-test in Table 14 showed a significant change $(\mathrm{p}=.000$, $\mathrm{t}=14.810, \alpha=5 \%)$ on students's critical thinking. The result of pretest (mean $=50.55$, $\mathrm{SD}=12.873)$ and posttest $($ mean $=83.53, \mathrm{SD}=$ 7.020) showed increament in students's critical thinking. Hence, it can be concluded there was a significant improvement on students's critical thinking due to the intervention.

Table 14. Paired Sample Statistics

\begin{tabular}{cccccc}
\hline Pair & Mean & SD & d & t & $\begin{array}{c}\text { Sig. } \\
(2- \\
\text { tailed })\end{array}$ \\
\hline Pretest & 50.44 & 12.873 & 2.539 & 4.81 & .000 \\
Posttest & 83.53 & 7.020 & & & .000 \\
\hline
\end{tabular}

The effect size (d) was calculated with $d$ Cohen to determine the extent of the mean difference. The value of effect size is 2.539 which was above 0.8 . The effect size greater than 0.8 can be categorized as high [34]. Based on the calculation on G-Power, the power for $\alpha$ $=5 \%$ requires a sample size consists of 5 students. The sample of this study was greater than the required sample size. The conclusion CTBILM caused a high effect on the mean of students' critical thinking.

\section{CONCLUSION}

Based on the result of the study, CTBILM is feasible and effective to be used as a tool of learning Basic Mechanical Engineering subjects to promote critical thinking of the students of vocational high school. The result of the pretest average score was 50.44 and the posttest average score was 83.53. The average increment from pretest to posttest for critical thinking was 33.09. The result of t-test shows a significant difference $(\mathrm{p}=.000, \mathrm{t}=14.810, \alpha=0.05)$. This study hence concluded that CBTBILM is the potential to promote critical thinking. This study proved the potential of mobile learning in increasing students' critical thinking. Hence, further study of learning media which considers another aspect other than critical thinking in $4 \mathrm{C}$ character is recommended.

\section{REFERENCES}

[1] Badan Pusat Statistik, "Narasi Tunggal : Hari Kependudukan Dunia 2017: Masa Depan Demografi Indonesia dan Keseimbangan Pertumbuhan Penduduk," pp. 1-4, 2020.

[2] S. Maryati, "Dinamika pengangguran terdidik: tantangan menuju bonus demografi di Indonesia," Economica, vol. 3, no. 2, pp. 124-136, 2015, doi: 10.22202/economica.2015.v3.i2.249.

[3] Badan Pusat Statistik Indonesia, "Berita Resmi Statistik No.37/05/Th. XXIV, 05 Mei 2021: Keadaan Ketenagakerjaan Indonesia Februari 2021,”2021.

[4] N. Wibowo, "Upaya memperkecil kesenjangan kompetensi lulusan sekolah menengah kejuruan dengan tuntutan dunia industri," J. Pendidik. Teknol. dan Kejuru., vol. 23, no. 1, p. 45, May 2016, doi: 10.21831/jptk.v23i1.9354.

[5] L. Sugiyarti, A. Arif, and Mursalin, "Pembelajaran abad 21 di SD," Pros. Semin. dan Disk. Pendidik. Dasar, pp. 439-444, 2018.

[6] Zurweni, B. Wibawa, and T. N. Erwin, "Development of collaborative-creative learning model using virtual laboratory media for instrumental analytical chemistry lectures," AIP Conf. Proc., vol. 1868, 2017, doi: 10.1063/1.4995109.

[7] R. G. Saadé, D. Morin, and J. D. E. Thomas, "Critical thinking in e-learning environments," Comput. Human Behav., vol. 28 , no. 5, pp. 1608-1617, 2012, doi: 10.1016/j.chb.2012.03.025. 
[8] C. M. Worsnop, "Media Literacy Through Critical Thinking Teacher Materials Notices and Acknowledgements Your Use of This Document Copyrights and Trademarks Acknowledgements Media Literacy Resource Guide: Intermediate and Senior Divisions by Ministry of Education," 1999.

[9] K. Changwong, A. Sukkamart, and B. Sisan, "Critical thinking skill development: Analysis of a new learning management model for Thai high schools," J. Int. Stud., vol. 11, no. 2, pp. 37-48, 2018.

[10] NACE, "Class of 2016 Believes it is 'Career Ready,' but is it?," 2016.

[11] L. M. Murawski, "Critical thinking in the classroom and beyond," J. Learn. High. Educ., vol. 10, no. 1, pp. 25-30, 2014.

[12] E. D. Kusuma, G. Gunarhadi, and R. Riyadi, "strategies to improve critical thinking skills through problem-based quantum learning model at primary school," Int. J. Multicult. Multireligious Underst., vol. 5, no. 4, p. 123, 2018, doi: 10.18415/ijmmu.v5i4.213.

[13] G. McMahon, "Critical thinking and ICT integration in a Western Australian secondary school," Educ. Technol. Soc., vol. 12, no. 4, pp. 269-281, 2009.

[14] R.-A. Pilar, A. Jorge, and C. Cristina, "The use of current mobile learning applications in EFL," Procedia Soc. Behav. Sci., vol. 103, pp. 1189-1196, 2013, doi: 10.1016/j.sbspro.2013.10.446.

[15] F. T. Leow and M. Neo, "Interactive multimedia learning: Innovating classroom education in a Malaysian university," Turkish Online J. Educ. Technol., vol. 13, no. 2, pp. 99-110, 2014.

[16] M. E. A. Babiker, "For effective use of multimedia in education, teachers must develop their own educational multimedia applications," Turkish Online J. Educ. Technol., vol. 14, no. 4, pp. 62-68, 2015.

[17] F. Martin and A. K. Betrus, Digital Media for Learning. 2019.

[18] S. Bidin and A. A. Ziden, "Adoption and application of mobile learning in the education industry," Procedia - Soc. Behav. Sci., vol. 90, no. InCULT 2012, pp. 720-729, 2013, doi: 10.1016/j.sbspro.2013.07.145.

[19] S. Yoosomboon and P. Wannapiroon, "Development of a challenge based learning model via cloud technology and social media for enhancing information management skills," Procedia Soc. Behav. Sci., vol. 174, pp. 2102-2107, 2015, doi: 10.1016/j.sbspro.2015.02.008.

[20] R. S. Nadiyah and S. Faaizah, "The development of online project based collaborative learning using ADDIE model," Procedia - Soc. Behav. Sci., vol. 195, pp. 1803-1812, 2015, doi: 10.1016/j.sbspro.2015.06.392.

[21] I. M. Tegeh and I. M. Kirna, "Pengembangan bahan ajar metode penelitian pendidikan dengan ADDIE model," J. Ika, vol. 11 , no. 1 , p. 16 , 2013.

[22] S. C. Wibawa, "The design and implementation of an educational multimedia interactive operation system using Lectora inspire," Elinvo (Electronics, Informatics, Vocat. Educ., vol. 2, no. 1, pp. 74-79, 2017, doi: 10.21831/elinvo.v2i1.16633.

[23] N. C. Facione, P. A. Facione, and C. A. Sanchez, "Critical thinking disposition as a measure of competent clinical judgment: the development of the California critical thinking disposition inventory," J. Nurs. Educ., vol. 33, no. 8, pp. 345-350, 1994, doi: 10.3928/0148-4834-19941001-05.

[24] P. a. Facione, "Critical Thinking: What It Is and Why It Counts," Insight 
Assess., no. ISBN 13: 978-1-891557-07-

1., pp. 1-28, 2011.

[25] Tryggvi Thayer, Assessment and Teaching of 21st Century Skills (ATC21S) - ENTREASSESS.COM. 2018.

[26] Direktorat Jenderal Pendidikan Menengah Dasar dan Menengah, "KI\&KD SMK/MAK Teknologi dan Rekayasa," 2017.

[27] A. Madhuram, M, Kumar and M. Pandyamanian, "Cross platform development using flutter," Int. J. Eng. Sci. Comput., vol. 9, no. 4, pp. $21497-$ 21500, 2019.

[28] K. Bashir, "Understanding the role of user interface design in fostering students' learning process in a multimedia courseware learning environment: insights from a Malaysian case study," IIUM J. Educ. Stud., vol. 5, no. 1, pp. 93-109, 2018, doi: 10.31436/ijes.v5i1.148.

[29] R. B. T. B. Florence Martin Jerome Hoskins, "Development of an interactive multimedia instructional module," $J$. Appl. Instr. Des., vol. 3, no. 3, pp. 5-18, 2013.
[30] B. Habib and R. Aamir Raza Ashfaq, "Relationship between factors of quality models and the system development life cycle," Int. J. Comput. Appl., vol. 81, no. 10, pp. 39-44, 2013, doi: 10.5120/14051-2216.

[31] M. Ali and S. Noordin, "Hubungan antara kemahiran berfikir kritis dengan pencapaian akademik dalam kalangan pelajar Fakulti Pendidikan Universiti Teknologi Malaysia," J. Teknol., no. January 2012， 2012， doi: 10.11113/jt.v52.136.

[32] T. Mantoro, A. Andryani, R. Dewanti, and M. A. Ayu, "Promoting autonomous learning using ICT in school setting constructivist perspectives," $A d v$. Sci. Lett., vol. 23, no. 2, pp. 699-703, 2017, doi: 10.1166/asl.2017.7555.

[33] M. Saculinggan and E. A. Balase, "Empirical power comparison of goodness of fit tests for normality in the presence of outliers," J. Phys. Conf. Ser., vol. 435, no. 1, 2013, doi: 10.1088/17426596/435/1/012041.

[34] L. A. Becker, "Effect Size ( ES ) - Part I," no. 1993, p. 14, 2000. 